\title{
Otkrivajući značenje i smisao izabranih temâ i motivâ biblijsko- teološkoga opusa Adalberta Rebića
}

\author{
DAFNe VIDANEC* \\ • https://doi.org/ 10.31823/d.27.1.7 • \\ UDK: 27-23-31-05 Rebić, A. • Pregledni članak \\ Primljeno: 20. veljače 2018. • Prihvaćeno: 12. ožujka 2019.
}

${ }^{*}$ Dr. sc. Dafne Vidanec,

Veleučilište Baltazar

Zaprešić, Vladimira

Novaka 23, 10290

Zaprešić, Hrvatska, dvidanec@bak.hr

Sažetak: U radu se filozofskim izrazom svojstvenim istaknutim imenima filozofijske hermeneutike 20. stoljeća (Heidegger i Gadamer) promišlja smisao i značaj židovstva i na njega usko navezana hebrejskoga jezika prema uvidima biblijskoteološkoga opusa Adalberta Rebića. Adalbert Rebić bio je tuzemni, glasoviti teolog, bibličar, poliglot, hebreist, sveučilišni profesor i rimokatolički svećenik. Užemu akademskomu, kao $i$ širemu kulturnom krugu u matičnoj zemlji i izvan nje Adalbert Rebić ostao je zapamćen kao stručnjak za hebrejski jezik $i$ židovstvo. Ljudi svakodnevice, mediji pamte ime Adalberta Rebića zahvaljujući njegovu nesebičnu angažmanu u području javnih službi u razdoblju ranih devedesetih godina 20. st. u Vladinu uredu za prognanike i izbjeglice RH. Desetke generacija studenata Katolickoga bogoslovnoga fakulteta Sveučilišta u Zagrebu sjeća se trenutaka kada ih je Adalbert Rebić uvodio u tajne hebrejskoga jezika - jezika na kome se Bog obratio čovjeku; jezika koji je odigrao ključnu ulogu u razumijevanju povijesti spasenja i novozavjetne poruke uskrsnuća Isusova. A možda se najradije njegova imena sjećaju hodočasnici koje je Adalbert Rebić nebrojeno mnogo puta vodio u Svetu zemlju. Hebrejski jezik, židovstvo, Isusovo uskrsnuće, Sveta zemlja samo su neki medu motivima i temama o kojima će biti riječi u sadržaju ovoga rada koji je koncepcijski podijeljen u tri dijela (premda metodološki obuhvaća šest dijelova): u prvome dijelu rada autorica se, služeći se samo pjesnicima svojstvenim načinom - metaforama, fokusira na razumijevanje Adalberta Rebića kao pisca pri čemu ključnu ulogu, kako autorica zapaža, ima njegov osobni identitet, tj. karakterna postojanost 
bjelodana u njegovim stručnim radovima. Drugi dio rada opsegom je najveći i njime su obuhvaćene teme jezika, klasifikacija djela Rebićeva opusa s naglaskom na problemati$k u$ hebrejskoga jezika $i$ židovstva. Tré́a cjelina donosi autoričina osobna razmatranja rebićevski shvaćene ontologije jednoga hodočačćenja, odnosno sinopsis glavnih tema $i$ motiva Vodiča po Svetoj zemlji, jer je to djelo, prema autoričinu osobnu mišljenju, uz Isusovo uskrsnuće ključno za razumijevanje Adalberta Rebića, njegova života, djela $i$ rada.

Ključne riječi: Adalbert Rebić, identitet, židovstvo, hebrejski jezik, Sveta zemlja.

\section{Status quaestionis}

Jedna među najtežim stvarima na ovome svijetu koji je, onima koji su skloniji metafizičkom promatranju stvarnosti, ${ }^{1}$ tako efemeran, a opet $u$ vječnom nastajanju i djelovanju uperenom prema eshatološkim determinantama dohvatljivima u pojmovima smrti, uskrsnuća, vječnoga života; dakle jest govoriti o ljudima koje, moglo bi se kazati, krasi odlika karakterne postojanosti ${ }^{2}$.

Kada je riječ o Adalbertu Rebiću ${ }^{3}$, ta karakterna postojanost u smislu moralne kakvoće, da se poslužimo konceptom suvremenoga mislioca Charlesa Taylora, od-

\footnotetext{
${ }^{1}$ Slijedimo li Aristotelovo poimanje, riječ bi bila o »pjesnicima i filozofima « o kojima Aristotel govori u $O$ pjesničkom umijeću [citirano prema Dukatovu prijevodu u izdanju Školske knjige 2005. god.]. Pjesničkom i filozofskom karakteru svojstvena je, da se poslužim prirodoznanstvenom terminologijom, $z$-dimenzija. U prirodoznanstvenoj terminologiji z-dimenzija, uz dimenziju $\mathrm{x}$ (dužina) i y (širina), označuje visinu, odnosno dubinu.

Referirajući se na Adalberta Rebića kojemu je ovaj rad i posvećen, može se reći da je njegovim djelima svojstvena ta z-dimenzija (shvaćena kao dubina misli i osjećanja) koja je bjelodana u Rebićevu lijepom, stilski vrlo dotjeranom, a gramatički preciznom izrazu teološki koncipiranih misli nadahnutih biblijskom tematikom. To nije čudno jer kao veliki poznavatelj tema i problematike Staroga zavjeta Adalbert Rebić i u literarnom pogledu slijedi put biblijskoga pisca sâma, koji se, kako bi dočarao Božju veličinu, nerijetko služi metaforama poput »gorućega grma « (Izl 3, 1-6).

Kada je riječ o Adalbertu Rebiću, može se kazati da je on i uz osnovnu teološku nomenklaturu i kao pisac posjedovao osjećaj za predočavanje z-dimenzije biblijsko-teoloških tekstova čitateljima općenito, a posebice svojim studentima kojima je predavao Biblijsku egzegezu Staroga zavjeta: Petoknjižje i proroka Amosa, tako da tko god uronio u proučavanje Rebićeve misli ne može ne zaključiti da je riječ o jednom teološkom peripatetiku koji je u teološkom, egzegetskom naučavanju uvijek slijedio put dubine teološke, biblijske misli i poruke.

${ }^{2}$ Neologizam koji je autorica skovala za potrebe ovdje bjelodanih istraživanja, a po uzoru na Aristotelovu koncepciju tzv. »karakternih vrlina «.

${ }^{3}$ Adalbert Rebić (23. siječnja 1937., Klenovec Humski - 20. veljače 2014., Zagreb) bio je hrvatski, rimokatolički svećenik, teolog, bibličar, filolog, poliglot i profesor biblijskih znanosti i hebrejskoga jezika pri Katoličkom bogoslovnom fakultetu Sveučilišta u Zagrebu; znanstvenik i prevoditelj; vodič, hodočasnik i turist u Svetoj zemlji; polivalentni službenik Zagrebačke nadbiskupije; suradnik/
} 
bljesak je njegova $\gg$ osobna identiteta «. Stoga je možebitno bolje govoriti o karakteru Adalberta Rebića. ${ }^{4}$

Ovo naše promišljanje, unatoč prevalentnom poetsko-filološkom, da ne kažemo peripatetičkom uzusu koji je, usuđujemo se tvrditi, svojstven piscima poput Adalberta Rebića jer su jezik i običaji (hebrejska kultura) središnji motivi njegovih teološki istraživanih filozofijskih promišljanja židovstva i Božje riječi i poruke općenito, dakle, ipak stremi tomu da, kada je riječ o Adalbertu Rebiću, ukaže na još jedno vrlo važno postignuće moralne filozofije iz posljednje trećine 20. stoljeća: čovjek, premda podvrgnut kontinuiranim promjenama, posjeduje ono nepromjenjivo: osobni identitet. Manifestaciju spomenute koncepcije moguće je prepoznati u životu, djelu i radu Adalberta Rebića.

Filozofijski mišljeno, baviti se, ovdje tek u ocrtu iznijetim, segmentima bi(bli)ografije, usuđujemo se kazati, jedne antropološke veličine kakva je, ništa manje nego u peru, u konkretnom životu bio Adalbert Rebić najprije zahtijeva utjecanje Heideggerovu imperativu da se misao nekoga mislioca (u našem slučaju: autora, nap. a.) ne može razumjeti na način da se njegovu misao dovede u upitnost, već mislima pokušati dohvatiti dubinu njegovih misli:

$\gg($ h)tjeti razumjeti mislioca iz njega samog podrazumijeva nešto drugo nego pokušaj da se pitanje nekog mislioca pitanjima unese u upitnost onoga što je mislio. $\ll^{5}$

Heidegger želi reći da (filozofsko) bavljenje nečijom misli zahtijeva uživljavanje ${ }^{6} \mathrm{u}$ misaoni svijet mislioca i njegove/njezine misli.

Ljudima je, s obzirom na njihovu temeljnu značajku u zbiljskome svijetu svekolikom prirodom obuhvaćenome - osobni identitet, a opet govoreno u duhu lite-

službenik Vlade RH sredinom devedesetih godina 20. st.; suradnik Židovske općine Zagreb te suradnik mnogih drugih institucija kulturno i akademski značajnih u Republici Hrvatskoj i izvan nje; par excellence profesor i predavač.

${ }^{4}$ Izraz karakter u kontekstu diskursa o Adalbertu Rebiću valja razumijevati kao specifičnu oznaku Rebićeva osobna identiteta koji se posvemašnje potvrdio kao tipično ljudski $\tau \dot{\lambda} \lambda o \varsigma$ manifestiran u njegovim riječima i djelima te u njegovu sveukupnom životu.

${ }^{5}$ Usp. M. HEIDEGGER, Što se zove mišljenje?, Zagreb, 2008., 124.

${ }^{6}$ Izrazom se koristim u misaonoj maniri Ricoeurova shvaćanja i tumačenja treće mimetičke razine. $\mathrm{O}$ mimetičkim razinama u kontekstu rasprave o temporalnoj dimenziji života vidi u: P. RICOEUR, Time and narrative. Vol. I., University of Chicago Press, 1990.

Ricoeura ovdje spominjemo kao bibliografsku referencu zbog njegovih vrijednih uvida bjelodanih u ranije spomenutom djelu gdje, među ostalim objašnjava relevantnost temporalne dimenzije ljudskoga života koji je tek shvatljiv kroz tzv. narativne metamorfoze - sistem dinamike slikovito posredovanih misli specifičan je i Adalbertu Rebiću kao piscu (nap. a.). 
rarnoga, moguće pronaći pandana u samoj prirodi - među zimzelenim drvećem koje je u svim četirima godišnjim dobima svojom pojavnošću isto: nepromjenjivo. Tu nepromjenjivost, odnosno (karakternu) postojanost želi se na ovome mjestu objektivirati likom Adalberta Rebića ${ }^{7}$, likom o kojem ne govore samo njegova literarna djela već i konkretno ljudsko djelovanje manifestirano u angažmanu za obična čovjeka patnika ${ }^{8}$, za (judeo)kršćansku zajednicu u cjelini.

Kako sva živa bića na ovome svijetu posjeduju njima svojstvene sposobnosti duše, objašnjava Aristotel u svojem djelu $O d u s ̌ i q$, tako ni ova naša usporedba Adalberta Rebića sa zimzelenim drvećem nije tek pjesnička metafora. Ona ima smisla ako je se nastoji iščitavati kroz sveukupnost života kao takvoga jer je u tom kompleksnom čovjekovu životu, u kojem ekosustav našega planeta dijelimo s biljkama i četveronožnim stvorenjima, jedino čovjeku dana mogućnost služenja razumom - »razumski dio duše $\ll{ }^{10} \mathrm{i} k$ tomu je on označitelj onoga što Aristotel dohvaća u sintagmi $\gg$ rasudni ${ }^{11}$ dio duše $\ll$, a teologija u logosu. Nije stoga lako govoriti o Adalbertu Rebiću kao o jednoj duši ${ }^{12}$ koja je unatoč primicanju prema osmoj dekadi života mogla još i dalje (u)disati onaj biblijski shvaćen (hebr.) ruah ('duh; dah') u koji je Rebićeva duša bila toliko zaljubljena i komu je posvetila cijeli svoj svećenički, teološko-znanstveni i hodočasnički životni poziv te aktivni građanski - profesorski život. Rebićeva je duša, nažalost, iz-dah-nula 20. veljače 2014. godine, na dan kada se u katoličkom kalendaru slavi Leon (Lav), uoči Međunarodnoga dana materinskoga jezika (koji se obilježava 21. veljače), a i ta činjenica da duša toga poliglota i zaljubljenika u hebrejski jezik napusti ovaj svijet na imendan Leona - Lava - kralja životinjskoga carstva govori za sebe sama: Rebićev se akademski, jednako kao znanstveni i hodočasnički éros može usporediti sa snagom i veličinom apetita duše u lava. Smatramo da nema boljega načina govorenja o jednoj lavljoj duši kakav je bio Adalbert Rebić od govora u duhu onoga što njegova duša iskonski bijaše: lavlja

\footnotetext{
${ }^{7}$ Ovaj rad nastao je na predlošku autoričina predavanja posvećenog Adalbertu Rebiću o trećoj obljetnici njegove smrti. Predavanje, naslovljeno Židovstvo perom Adalberta Rebića, održano je u dvorani Židovske općine u Zagrebu, a u organizaciji kulturnoga društva Miroslav Šalom Freiberger 28. ožujka 2017. godine. Tekstualni predložak predavanja koji potpisuje sâma autorica Rebićevo kršćanstvo kao 'moderna' judaizma objavljen je u časopisu Novi Omanut, siječanj, travanj (2017.).

${ }^{8}$ Aluzija na Rebićevu službu u Vladinu uredu za prognanike i izbjeglice RH.

${ }^{9}$ Usp. ARISTOTEL, O duši/Nagovor na filozofiju, Zagreb, 1987., ondje vidi: ISTI, O duši, II., 414a $3-414 \mathrm{~b} 3$.

${ }^{10}$ ARISTOTEL, O duši, III., 429a 4.

${ }^{11}$ Isto, II., 415 a 3.

${ }^{12}$ Ovdje se izrazom duša koristim dvojako: (1) na spoznajnoj razini, u teološko-eshatološkom smislu posredovano kršćanskim učenjem o uskrsnuću; (2) kao antropološkom klasifikacijom čovjeka: sinonim za osobu (nap. a.).
} 
duša. Jer kako bismo inače shvatili ljepotu Rebićeva literarnoga i oralnoga izraza, bilo da je riječ o autorskim ili prevoditeljskim radovima, ili pak predavanjima studentima, a koji je izraz izvirao iz njegova hrabra srca, ako ne kroz stihove sâme. I zato ovaj rad o Adalbertu Rebiću namjeravamo otpočeti Cesarićevim stihovima njegove nadasve poznate Pjesme mrtvog pjesnika:

$$
\begin{gathered}
\gg(\text {... ) Pred smrću ja se skrih (koliko mogoh) } \\
\text { U stihove. U žaru sam ih kovo. } \\
\text { Al zatvoriš za njih svoje srce, } \\
\text { Oni su samo sjen i mrtvo slovo. } \\
\text { Otvori ga, i ja ću u te prijeći } \\
\text { Ko bujna rijeka u korito novo. } \ll^{13}
\end{gathered}
$$

\section{O biblijsko-teološko-literarnom projektu Adalberta Rebića ${ }^{14}$}

Znanstveno-akademski uzus, kada je riječ o sinopsisu djela i života istaknutih ljudi neke političke zajednice koji su svojim misaonim angažmanom i praktičnim djelovanjem ostavili značajni biljeg na povijesti te zajednice, jest da se nečiju biografiju predstavi slijedeći određenu kronologiju događaja. Budući da smatramo da (biografskom) formalizmu nije uvijek mjesto u akademskom diskursu - pogotovo kada je riječ o onome što smo na prethodnim stranicama dohvatili u sintagmi lavlja duša - odlučili smo biografske elemente iz (većinom) javnoga života Adalberta Rebića iznijeti u formi stanovite hermeneutike mišljenja segmenata njegova javnoga djelovanja, čiji su plodovi utkani u kulturu, religiju i znanost jednoga društva koje nosi prerogativ judeokršćansko. Ti se plodovi, u prvome redu, odnose na bogato misaono, literarno i teološko stvaranje - riječju: biblijsko-teološko-literarni projekt Adalberta Rebića kojemu je imanentna jedna osobna biografija - »osobni identitet $\ll{ }^{15}$ općenito dohvatljiv s pomoću njegova opsežnoga misaonoga stvaralaštva: njegovih radova, prijevoda, knjiga, javnih predavanja, gostovanja u medijima; međutim iznad svega u njegovim fakultetskim predavanjima koja su Rebićevom erudicijom, sposobnošću da studente zainteresira (za neku svoju znanstvenu ili pak hodočasničku priču, nap. a.) do stupnja u kojem bi studenti sami postali uključivi dio te priče (o biblijskim starinama, genezi hebrejskoga jezika ili pak o Knjizi Postanka)

\footnotetext{
${ }^{13}$ D. CESARIĆ, Voćka poslije kiše. Izabrane pjesme i memoarski zapisi, Zagreb, 1983., 14-15.

${ }^{14}$ Sintagma obuhvaća dvoje: (1) događaj zabilježen perom novozavjetnih pisaca evanđelja: Mateja, Marka, Luke i Ivana i (2) naslov glasovite Rebićeve knjige u kojoj je predstavio rezultate istraživanja temeljnih izvora o Isusovu uskrsnuću razumijevanih »egzegetskom metodom - analiza redakcije i povijest predaje « (Evanđeljâ, nap. a.).

${ }^{15}$ Sintagmom se koristim u misaonoj maniri kanadskoga filozofa Charlesa Taylora.
} 
plijenila pozornost studenata mnogih generacija Katoličkoga bogoslovnoga fakulteta Sveučilišta u Zagrebu - sve do njegova umirovljenja 2007. godine.

Tko god želi čitati kronologiju Rebićeva života, dostupno mu/joj je na tisuće biografskih referenci ${ }^{16} \mathrm{u}$ okviru čijega sadržaja potencijalni čitatelji mogu pronaći izvorište podataka o tom uglednom članu hrvatske akademske i (judeo)kršćanske zajednice u tuzemstvu i inozemstvu. O čovjeku koji je, među ostalim, ostao zapamćen i kao promicatelj dijaloga između židovstva i kršćanstva. Spona toga dijaloga bio je upravo hebrejski jezik. Potonje je razlog zbog kojega se u ovom radu ponajviše usredotočujemo na tematiziranje značenja hebrejskoga jezika u akademskom stvaralaštvu Adalberta Rebića, prikazano pak jednim unakrsnim pregledom izabranih misli (o židovstvu i hebrejskom jeziku, nap. a.) onih djela iz Rebićeva opusa koja su nezaobilazna u shvaćanju i tumačenju židovstva i hebrejskoga jezika u kontekstu kršćanske poruke Isusova uskrsnuća.

Tema Isusova uskrsnuća, smatra se, zaslužila je više jedno filozofijsko (hermeneutsko) pozicioniranje, jednako kao i njezin autor - Adalbert Rebić. Njegova biografija i znanstveno-popularno stvaralaštvo zavrijedili su mnogo više od prikaza puke, kronološki oblikovane taksonomije događaja koji su obilježili život i djelovanje Adalberta Rebića u onom teleološkom i eshatološkom pogledu: njegova osobna predanost (kršćanskoj) vjeri i njezinu osnivaču bjelodana je i u misaonom djelu i u konkretnom djelovanju i ponašanju. ${ }^{17}$

\footnotetext{
${ }^{16}$ Upiše li se pojam Adalbert Rebić u Googleov pretraživač, isti će izbaciti preko 63700 referenci (zadnja provjera datirana 13. veljače 2018.).

${ }^{17}$ Kako bih ilustrirala tu isprepletenost osobne odanosti Isusu i njegovu učenju u praktičnom životu, opisat ću jednu epizodu koju imam zahvaliti svom radnom kolegi, profesoru ekonomske skupine predmeta pri Veleučilištu Baltazar Zaprešić koji je želio ostati anoniman. Ta epizoda dokazuje da je u razdoblju između 1991. i 1995., kada je Adalbert Rebić obnašao dužnost predstojnika Vladina ureda za prognanike i izbjeglice $\mathrm{RH}$, za tu tešku ekonomsku i moralnu ratnu situaciju u kojoj se zatekao puk Hrvatske i regije svijet pokazao podosta razumijevanja, pa je u ondašnju Hrvatsku sa svih strana pristizala humanitarna pomoć i organizirale su se različite humanitarne akcije za spas ljudi koji su uslijed rata ostali bez svojih domova, zavičaja. Tako su i financije pristizale u ranije spomenuti Ured kojemu je na čelu bio Adalbert Rebić. U to je vrijeme izvor ovdje bjelodanih informacija obavljao računovodstveno-revizorske poslove vezane za spomenuti Ured, pa je imao uvid $\mathrm{u}$ novčane tijekove Ureda. Prema iskazu izvora iz toga Ureda, $\mathrm{u}$ vrijeme kada ga je vodio Adalbert Rebić »nikada nije falila nijedna lipa «, a sâm se Rebić odrekao i honorara u korist potrebitih. Ta nam epizoda govori koliko je Adalbert Rebić bio ne samo častan i pošten nego - $u$ aristotelovskom smislu - krjepostan u pravom smislu te riječi. (Izvor: neformalni razgovor s radnim kolegom u prostorima Veleučilišta Baltazar u rano proljeće 2017. godine.).
} 


\subsection{JEZIK KAO ŽIVOT U KONTEKSTU REBIĆEVIH IZABRANIH PROMIŠLJANJA O ŽIDOVSTVU}

Koliko god da je nebo prostrano, koliko god da su morâ duboka, a zemlja da je plodna, nijedno se među njima svojom veličinom ne može mjeriti i usporediti $s$ veličinom intenziteta ljubavi koju je Adalbert Rebić u posljednjim četirima, pa i više desetljeća perom zabilježio o židovstvu, židovskoj kulturi i njoj svojstvenu i jedinstvenu hebrejskom jeziku te židovskoj teologiji.

Zahvaljujući intelektualnoj tradiciji njegovanoj u teološkom, kršćanskom duhu, kao i naglašenu propovjedničkom i predavačkom daru, kada je riječ o prenošenju znanja o korijenima kršćanske religije s pomoću razumijevanja bîti jezika općenito, a posebice jezika na kojem se prema vjerovanju Židova i kršćana Bog objavio čovjeku (Post 1,26) - hebrejskoga jezika, Adalbert Rebić bio je poznat i prepoznat ne samo unutar granica matične institucije u kojoj je četiri desetljeća studente poučavao ljepoti, smislu i značaju hebrejskoga jezika, zemlje u kojoj se rodio, odrastao, školovao se, radio te naposljetku, metaforički mišljeno, »predao svoj život u ruke Gospodnje « anno domini 2014. nego je njegova teološka misao ostala zapažena diljem Europe, kao i izvan granica europskoga kontinenta.

Možemo kazati da je upravo u židovskoj teologiji Adalbert Rebić prepoznao ne samo vrelo biblijski-literarno interpretiranoga teološko-fundamentalnoga razumijevanja vjere u Isusovo uskrsnuće nego je Rebić ponajprije bio fasciniran spoznajom da se Bog objavio biblijskom čovjeku (usp. Post 7, 1; 9, 1; 12, 1, Izl 3, 14) ${ }^{18}$ na jeziku čija je ljepota upravo sadržana u samome činu te Božje objave, činu koji pak odzvanja glasovitom frazom $\gg$ ja sam koji jesam $\ll$ (prema hebrejskoj transliteraciji i izgovoru) ehjeh ašer ehjeh - JHVH (Izl 3, 14).

Samo oni koji su imali čast da budu obrazovani pod misaonom i intelektualnom palicom toga poliglota ${ }^{19} \mathrm{i}$ eksperta za Bibliju i biblijske znanosti znaju koliko je Rebić bio zaljubljen u biblijsku, židovsku teologiju i hebrejski jezik, do mjere u kojoj nema nijednoga djela iz znanstveno-popularnoga, uređivačko-literarnoga i/ili akademskoga opusa u kojem Rebić, i izravno i nerijetko među redcima, ne govori o značenju hebrejskoga jezika i židovstva, ali prije svega u kontekstu novozavjetne poruke o Isusovu rođenju, smrti i uskrsnuću.

${ }^{18}$ Biblijski se citati navode prema ključu koji je bjelodan u Jeruzalemskoj Bibliji, 2014. (nap. a.).

${ }^{19}$ Autorica je, s obzirom na to da je nekadašnja Rebićeva studentica (u razdoblju između 1994./1995. - 1999. pri Katoličkom bogoslovnom fakultetu Sveučilišta u Zagrebu), upoznata s činjenicom da je Adalbert Rebić bio istinski ljubitelj jezika i poliglot te je govorio (oko) devet stranih jezika, među kojima tri, hebrejski, arapski i sirsko-aramejski, pripadaju semitskoj skupni jezika, a preostalih petšest jezika obuhvaćalo je engleski, njemački, francuski, talijanski te još dva klasična jezika, latinski i grčki. 
Donosimo nekoliko redaka iz Rebićeva djela Isusovo uskrsnuće: izvješća - poruka - vjera, koje je ranih sedamdesetih godina unutar tuzemnih, rimokatoličkih crkveno-akademskih krugova izazvalo polemike, pa i negativne recenzije ${ }^{20}$, a redci koje ovdje donosimo obuhvaćaju razumijevanje temeljnih razlika između Židova i kršćana s obzirom na vjerske, tj. obredne (liturgijske), ali, prije svega, općeživotne, moralne posebnosti:

»'(p)rvi dan u tjednu' je nedjelja, koju su Židovi u prvokršćansko vrijeme nazivali 'dan nazarećana'. Ovaj dan postaje veoma zarana, u prvokršćanskim zajednicama u Jeruzalemu, danom Gospodnjim jer je na taj dan Krist uskrsnuo od mrtvih, odnosno točnije, jer su učenici Isusovi na taj dan otkrili prazan Grob i na temelju Božje objave spoznali otajstvo Kristova proslavljenja i uskrsnuća. ${ }^{21}$

Nadalje sljedeći redci daju svjedočanstvo o tome na koji je način Adalbert Rebić doživljavao hebrejski jezik, njegovu povijesnu dimenziju i kako je s lakoćom, a opet znanstveno, metodološki, nikada ne zaboravljajući taj tzv. znanstveni uzus karakterističan zaljubljenicima u znanost, pisao:

»(h)ebrejski je jezik jedan od najstarijih jezika, postoji već preko tri tisuće godina bilo kao govorni jezik bilo kao jezik sakralne i profane židovske književnosti. Spada u stare semitske jezike koji su bili u uporabi već u 4. tisućljeću pr. Kr. te ima vrlo uzbudljivu i bogatu prošlost. (...) Hebrejski je jezik jezik hebrejskog (židovskog izraelskog) naroda, posvjedočen u vjerskim spisima Starog zavjeta (IX. do II. st. pr. Kr.), u spisima učenih rabina kao što su Mišna, Midraši, Talmud (I. do V. st. po Kr.), srednjevjekovnih židovskih djela kao što su kabala (Zohar) i opet je zaživio u suvremenoj židovskoj (izraelskoj) literaturi (XIX. i XX. st.). Zove se hebrejski jer su se njime služili Hebreji od useljenja u Kanaan u XIII. st. pr. Kr. pa sve do danas. Međutim, nisu Hebreji stvorili taj jezik, nego je on još prije useljenja Izraelovih plemena u Kanaan postojao i njime su govorili prastanovnici te zemlje već od 4. tisućljeća pr. Kr. i stoga se on i u Bibliji zove 'kanaanski' jezik (hebr. Sefat kena'an; Iz 19,18). $\ll^{22}$

Možemo kazati da je Adalbert Rebić mislio da bi čovjek kršćanin općenito mogao razumjeti Isusov nauk, Njegov fatum, kao i ranija, starozavjetna proroštva prožeta mesijanskom vizijom (npr. Izaija, Psalmi), najprije mora razumjeti jezik - hebrejski

${ }^{20}$ Usp. A. ŠKRINJAR, Adalbert Rebić. Isusovo uskrsnuće, u: Obnovljeni život 28(1973.)3, 286-300; također vidi: A. REBIĆ, Isusovo uskrsnuće. Izvješća - poruka - vjera, Zagreb, ${ }^{2} 1999 ., 7$., bilj. 3.

${ }^{21}$ A. REBIĆ, Isusovo uskrsnuće, 82.

${ }^{22}$ A. REBIĆ, Značajke biblijskog hebrejskog jezika u odnosu na spoznaju i interpretaciju, u: Bogoslovska smotra 73(2003.)4, 631-648., ovdje 631-633. 
jezik na kojem se Bog objavio ljudima i kroz jezik s ljudima stupio u jedan bilateralni odnos, u kontakt, u vezu ili savez:

$\gg(\mathrm{m})$ isao o Bogu, čovjeku i svijetu u kojem živimo možemo izraziti mitskim, filozofskim i teološkim načinom govora. Možemo o Bogu govoriti i pjesnički, možemo ga izraziti u slikama, kipovima, simbolima, pa i u glazbi... Svaki je od tih načina izražavanja valjan, ali se jedan od drugoga razlikuju i vremenski su se u povijesti pojavljivali jedan poslije drugoga. Mitski način razmišljanja i govora jednostavno je jedna od etapa razvoja ljudskog izražavanja. I nije zapravo nikad posve nestao iz povijesti ljudskog razmišljanja. U Hebrejskoj Bibliji susrećemo mitski jezik na mnogim mjestima, od Knjige Postanka do Knjige Otkrivenja, od opisa stvaranja svijeta do prikazivanja Božjeg svijeta ('nebo' kao simbol Boga i Božjeg svijeta, 'kraljevstvo Božje' kao izraz za novi svijet, Božji svijet u kojem su svi ljudi braća, jer su sinovi i kćeri jednoga Boga). $\ll{ }^{23}$

Jezik je, može se reći iščitavajući Rebićev teološki opus kojemu su imanentna promišljanja o starozavjetnoj, biblijskoj teologiji i hebrejskom jeziku, sredstvo uz pomoć kojega je, kako se prethodno kazalo, Bog sklopio savez s čovjekom i taj je savez utemeljen u dijalogu kojemu je (hebrejski) jezik ključni element, a riječ (hebr. dabar) njegov temelj i izvor:

»Za Izraelca 'riječ' je imala dinamičko, kreativno i dijanoetičko značenje, tj. 'riječ' je bila shvaćena kao neka pokretačka snaga, stvoriteljska sila i ujedno sredstvo prenošenja misli. Moć 'riječi' krije se u moći osobe. Kad osoba govori očituje se prema vani oslobađajući svoju duševnu (psihičku) energiju. (...) Kad je ljudska riječ obdarena takvom silom i moći, kakvom li je tek silom i snagom obdarena Božja riječ, pa zato Psalmist kliče: 'Jahvinom su riječju nebesa sazdana i dahom usta njegovih sva vojska njihova' (Ps 33.6), a pisac biblijskog izvještaja o stvaranju pripisuje Božje stvaranje svijeta i čovječanstva sili i snazi Božje riječi: 'I reče Bog: Neka bude svjetlost! I bi svjetlost.' (Post 1,3$) \ll$

Ono što, prema Rebiću, čovjeka ponajviše čini sličnim Bogu (Post 1, 26), a što je razvidno temeljem prethodno citiranoga ulomka iz sjajnoga članka naslovljenoga Značajke biblijskog hebrejskog jezika u odnosu na spoznaju i interpretaciju ${ }^{24}$ jest govor

${ }^{23}$ Isto.

${ }^{24}$ Spomenut ću da je članak objavljen u časopisu Katoličkoga bogoslovnoga fakulteta u Zagrebu, Bogoslovska smotra 74(2003.)4, 631-648; inače je članak napisan u svrhu referata održanoga u sklopu simpozija o spoznaji i interpretaciji u organizaciji Instituta za filozofiju u Zagrebu 2003. godine. Zanimljiva je uvodna, prva fusnota u tekstu članka u kojoj sâm autor kaže da članak posvećuje svojim studentima (...) koje je 35 godina (1968. - 2003.) uvodio u tajne hebrejskoga jezika (nap. a.). 


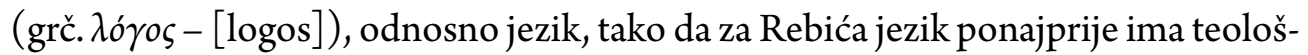
$\mathrm{ku}$ - objaviteljsku i soteriološku, metafizičku ili nadnaravnu funkciju i dimenziju. Zbog toga je Adalbert Rebić cijeli osobni i javni, društveno-poslovni život posvetio proučavanju toga božanskoga jezika i njegove (semitske, nap. a.) kulture i to je proučavanje inherentno cijelom Rebićevu znanstvenom, znanstveno-popularnom i akademskom opusu.

\section{Hermeneutika jedne biblijsko-teološke interpretacije: kršćanstvo - (post)moderna judaizma ${ }^{25}$}

Zanimljivo je da se upravo među redcima Gadamerovih Ogleda o filozofiji umjetnosti, djela koje spada u antologiju estetike - filozofije lijepoga, otkrio način na koji bi bilo zgodno u ocrtu prikazati (tj. upozoriti) na ključne spoznajne elemente Rebićeva znanstvenoga i literarnoga opusa kojima je imanentna relacija s našom temom u ovome dijelu rada, a to je koncept rebićevskoga židovstva. Taj koncept reflektira Gadamerov opis diskurzivne svijesti koja je na djelu u današnje vrijeme kada raspravljamo o bîti umjetničkoga djela, polemičnost između dvaju diskurzivnih tabora: (1) tabora koji zastupa mišljenje da sveukupnost noviteta u umjetnosti koje (novitete) je moguće svesti pod zajednički nazivnik moderna (umjetnost) nema nikakve veze s umjetnosti u pravom smislu te riječi i (2) tabora koji smatra da je umjetnost shvaćena u klasičnom, aristotelovskom smislu kao mimesis (oponašanje), pojednostavljeno, stvar prošlosti. No Gadamer nalazi jedan treći put, čineći određenu - upotrijebit ću izraz M. Heideggera - »dekonstrukciju « razumijevanja umjetnosti od antike do novoga doba te kao glavne svjedoke (novoga doba shvaćanja umjetnosti, nap. a.) uzima Kanta i Hegela, nalazi jedan srednji put, pokušavajući objasniti uzrok koji je doveo do toga da se s obzirom na svrhu umjetnosti i umjetničkoga djela dogodio zaokret te se naglasak s oponašanja premjestio na pojam stvaranja. To premještanje ima ontološke temelje. Tako i ovo naše promišljanje o Rebićevoj koncepciji židovstva slijedi jedan srednji put - definirat ću to ontologijom biblijsko-teološke interpretativnosti ${ }^{26}$ bjelodane $u$ misaonoj maniri

\footnotetext{
${ }^{25}$ Ovdje se neće objašnjavati semantika izraza (post)moderna jer to nije tema naših promišljanja bjelodanih u ovome radu. Izrazom (post)moderna koristimo se na tragu Arnolda Toynbeeja kao oznakom za sveukupnost fenomena koji karakteriziraju našu epohu u povijesnom i društvenom pogledu jer u kulturno-umjetničkom pogledu pak izraz moderna koji stoji u riječi (post)moderna označuje sasvim nešto drugo - jednu svijest načetu u 18./19. stoljeću u kontekstu diskursa o lijepoj umjetnosti. Dakle (post)moderna bi se u kontekstu ovdje naznačenoga diskursa mogla shvatiti i tumačiti kao kognitivno-temporalno obilježje vremena u kojem živimo, a koje je sada već obilježeno i višestrukim post-ovima.

${ }^{26}$ Sintagma je oblikovana u svrhe ovdje bjelodane rasprave, $\mathrm{s}$ time da izraz ontologija u spomenutoj sintagmi ne označuje filozofsku disciplinu ni spoznajno-teorijski alat, već se autorica izrazom ko-
} 
Adalberta Rebića, poradi čega je njegov opus možebitno i teško razumjeti izvan akademske sfere, a opet, $s$ druge pak strane, to je lajtmotiv utkan u naše istraživanje Rebićeva biblijsko-teološkoga literarnoga opusa kojemu istraživanju jest svrha da Rebićeva koncepcija židovstva bude razumljiva ljudima općenito, a ponajprije onima koji pripadaju određenoj kulturnoj zajednici koja promiče židovski identitet $u$ tuzemnoj akademskoj sferi i izvan nje.

Što i tko misli o Rebićevu shvaćanju i tumačenju židovstva izvan (kršćanskih) akademskih krugova teško je na ovome mjestu govoriti jer je recepcija njegova akademskoga i znanstvenoga te kulturnoga stvaralaštva projekt u nastajanju. Možemo kazati da gotovo i nema konkretnoga znanstvenoga rada čiji bi sadržaj prezentirao bilo koji segment Rebićeva učenja i poimanja. Želi se reći da je recepcija Rebića i njegove misli unutar tuzemnih akademskih i kulturnih krugova neznatna. Tako da ovo naše promišljanje, među ostalim, ide za tim da tu recepciju osnaži, u svakom pogledu, kao i za tim da: (1) u spoznajnom smislu otkloni $\gg$ jednotračni $\ll{ }^{27}$ pogled na Rebićev doprinos židovskoj kulturi i židovskom (religijskom) identitetu unutar tuzemne akademske i šire kulturne zajednice i (2) metodologijski da - metaforički - razgrne tamni veo koji se nadvio nad razumijevanje primarno soterioloških i eshatoloških, a sekundarno epistemičkih temelja na kojima počiva židovstvo, odnosno judeokršćanstvo. Jednako tako da se tuzemna židovska interpretativna strana, kada je riječ o židovstvu, njegovim korijenima, razumijevanju izvan horizonta Talmuda i općeprihvaćenih tumačenja pojedinih rabinskih škola u svijetu dakle senzibilizira za interpretacije o židovstvu dane u peru Adalberta Rebića za koje se misli da mirišu na monolitno, kršćansko, tj. katoličko promatranje i razumijevanje bîti hebrejske religije - judaizma.

risti kako bi naglasila zagonetnost Rebićeve biblijsko-teološke interpretacije, pri čemu se upravo hebrejski jezik, među ostalim, shvaćen kao veza između Boga i čovjeka, kako to Rebić objašnjava, može shvatiti kao zagonetka. Zagonetka je to da se Bog obratio čovjeku na njemu razumljivom jeziku. A budući da je zagonetka, gramatički, apozicija bitku, kako se zaključuje temeljem Heideggerovih eksplikacija u Bitku i vremenu, dadne se zaključiti da je tu skrivenost, tj. zagonetnost (Heideggerova bitka) Adalbert Rebić iz filozofsko-hermeneutičkoga diskurzivnoga miljea transponirao u teološki, povijesno-eshatološki milje kao svojevrsni spoznajni alat, uz čiju bi pomoć što uvjerljivije dočarao bît hebrejskoga jezika. A ona se sastoji u savezu koji je Bog sklopio s čovjekom na čovjeku razumljiv način: jezik - hebrejski jezik. Stoga (hebrejski) jezik uz imanentnu soteriološko-eshatološku dimenziju ima komunikativnu i moralnu dimenziju. Već sâmim time što je čovjek obdaren kapacitetom govora prema (judeo)krščansko-teološkom učenju čovjek se, uzvraćajući odgovor Bogu, potvrđuje kao onaj koji je bogosličan, uistinu Bogu nalik. Tako da izraz ontologija u spomenutoj sintagmi ne podrazumijeva razumijevanje Boga, nego onoga što pri Bogu kao »pri biću a priori leži zagonetka «. Jezik je ta sfera unutar koje čovjek cirkulira »u razumijevanju bitka «, teološki mišljeno: Boga. - O bitku kao zagonetki vidi: M. HEIDEGGER, Bitak i vrijeme, Zagreb, 1985., 4.

${ }^{27}$ Heideggerov izraz. 
Osim izvora o židovskoj religiji, kulturi, društvu i jeziku koje potpisuje Adalbert Rebić, za potonje se teško može pronaći znanstveno provjerljivi, objektivni epistemički izvori u okviru akademske i znanstveno-stručne sfere na tuzemnom govornom području jer nema objavljenih, sistematski autentičnih, metodološki sveobuhvatnih, epistemološki integralnih studija o židovstvu do onih koje je Adalbert Rebić za života objavio. Također ćemo spomenuti i to da takvih istih studija nema o životu, djelu i radu teologa, filologa i hebreista Adalberta Rebića. Tako da je ime Adalberta Rebića unutar tuzemnoga akademskoga okvira (pa i izvan njega, nap. a.) postalo sinonimom za ekspertizu na području biblijske teologije i hebrejskoga jezika, židovstva općenito.

\section{O Rebićevu bibliografskom opusu posvećenom pitanju židovstva}

\subsection{KLASIFIKACIJA DJELÂ S OBZIROM NA PRIRODU PROBLEMATIKE}

Kako bi čovjek razumio rebićevsko židovstvo (nap. a.), dakle Rebićev misaoni i praktični pristup židovskoj kulturi i narodu, neophodno je iščitati i proučiti veliki dio literarnoga opusa koji je Rebić ostavio iza sebe, a koji (naoko izbrojeno) obuhvaća dvadesetak knjiga, uz značajan ${ }^{28}$ broj znanstvenih članaka i drugih publicističkih radova. Taj opus s obzirom na Rebićevu ekspertizu, interesno područje i predmet istraživanja možemo podijeliti u nekoliko razina.

(1) Tumačenje i shvaćanje Petoknjižja (hebr. Tôra): (1a) s posebnim naglaskom na literarni tuzemni i inozemni znanstveni doprinos egzegezi Knjige Postanka bjelodan u djelima iz 1996. godine: Stvaranje svijeta i čovjeka i Središnje teme Staroga zavjeta; U tebi će biti blagoslovljeni svi narodi (2011.), (1b) te refleksijama a conto uloge i karaktera proroka kao Božjih posrednika i opominjatelja (nap. a.) izraelskoga naroda zabilježenima u Amosu - proroku pravde (1994.), Proroku - čovjeku Božjem (1996.), Proroku i njegovoj preljubnici (2005.).

(2) Egzegetski opus Novoga zavjeta gdje se Rebić ponajprije kao svećenik, potom kao teolog, mislitelj i pisac usredotočuje na lik, djelo, život i smrt Isusa Krista: ranije spomenuto djelo Isusovo uskrsnuće - izvješća - poruka - vjera ( $\left.{ }^{\mathrm{I}} 1972 .{ }^{2}{ }^{2} 1999.\right)$, Biblijsko-teološki pabirci o Isusu Kristu (2005.).

\footnotetext{
${ }^{28}$ Tijekom pripremanja materije koja bi poslužila kao teorijski predložak za jedan sinopsis literarnoga opusa posvećenoga židovstvu nije se išlo za taksonomijom Rebićeva sveukupna stvaralaštva, tako da ovo elaboriranje ne uključuje numerički izvedene vrijednosti koje se referiraju na točan broj radova - bilo znanstvenih, popularnih, homiletskih koje je Adalbert Rebić napisao za svoga života. Taj pothvat ostavlja se za drugu prigodu kojoj će ime Adalberta Rebića biti glavni akter. Ovo elaboriranje većinom se fokusira na ona Rebićeva djela u kojima se Rebić bavi isključivo problematikom židovstva i hebrejskoga jezika te hebrejske kulture (religije).
} 
(3) Biblijskom egzegezom protumačena teologijsko-arheologijska provenijencija shvaćanja biblijskog svijeta zbijena pod naslovom Biblijske starine ( ${ }^{1} 1983$.), Jeruzalem (2009.).

(4) Svećeničko-homiletska i pashalna djela, primjerice Homilije za liturgijsku godinu B: biblijsko-teološki vid (2009.), Biblijski i crkveno-povijesni vidovi euharistije $i$ križa (2005.), Homilije za liturgijsku godinu C - biblijsko-teološki vid (2006.), Uz Božić (2007.).

(5) Povijesno-teologijsko-kulturologijska razmišljanja obuhvaćena naslovom Vodič po svetoj zemlji ( ${ }^{1} 1983 . ; 2010$. - V. ed.).

Naposljetku (6) filološki opus sintetički obrađen i dorađen u Slovnici hebrejskog jezika s čitankom (2011. - V. ed.).

Spomenuli smo ona Rebićeva djela koja su možebitno ne toliko naslovom zanimljiva i čitateljima primamljiva, koliko su samim sadržajem intrigantna. Riječ je o cijeloj semantičkoj lepezi obuhvaćenoj samo Rebiću svojstvenom interpretativnom načinu razumijevanja ishodišne dimenzije ljudskoga života - Boga. Zatim načinu koji se odlikuje narativnim elementima: priča o čovjekovu postanku koja ima fabulu - radnju: to je stvaranje, življenje, spasenje, otkrivenje itd., aktere: izraelskoga čovjeka i njegova jedinstvenoga Boga. Priča ${ }^{29}$ koja je pisana na samo za nju svojstvenom hebrejskom jeziku; priča koja ima svoj početak - riječ, zaplet obojen mesijanskim koloritom koji svoju prepoznatljivost nalazi u novozavjetnom Židovu Isusu Kristu. Priča koja ima peripetiju u kojoj je Ivan Krstitelj glavni akter jedne eshatologije obilježene kerigmatskim aspektom mesijanske nade. Priča koja ima svoj rasplet $\mathrm{u}$ kojem se događa prokazivanje te nade. Međutim atipična priča koja nema kraj poput ostalih priča koje ga imaju jer je izvor od koje je sačinjen njezin temelj nadmaterijalan; kršćani ga zovu uskrsnuće, a Židovi višetisućljetnim kultiviranjem mesijanske nade koja još živi - koja je tû, možemo kazati na tragu Rebića. Tako Rebić u Središnjim temama Staroga zavjeta 11. poglavlje posvećuje duhu Božjem, ne otpočevši tuđicom - etimologijom, kako bi možebitno bilo očekivano od jednoga poliglota i filologa, nego lijepom riječju koju prepoznaje samo duh (našega) jezika - »izrazoslovljem « što je sve riječ duh (hebr. ru'ah) značila biblijskom čovjeku: »vjetar, oluja, životni dah, životvorni duh, počelo života «. Želi se reći da je izraelski čovjek mesijansku nadu kultivirao te je simbolički izražavao izrazom ru'ah, a to nije malo, kako smo prethodno vidjeli temeljem pročitanih segmenata

${ }^{29}$ Izrazom priča koristim se u smislu i prema shvaćanju Charlesa Taylora, bjelodanom u njegovu filozofskom djelu naslovljenom Izvori sebstva: razvoj modernog identiteta (Zagreb, 2011.), u kojem Taylor donosi njemu svojstvenu filozofsku kritiku povijesne interpretacije onoga što dohvaćamo u izrazu identitet, tj. sebstvo. 
Rebićeva djela u kojem raspravlja o trima razinama jezika: fenomenološkoj, morfološkoj i semantičkoj.

\subsection{AdALBERT REBIĆ: 》UMJETNIK RIJEČI $\ll$}

Izborom naslova svojih literarno-znanstvenih djela Rebić se svojim čitateljima samo naizgled otkriva kao formalistički pisac koji odveć umuje. Upravo nasuprot, tko je god ušao u dubinu njegovih riječi i misli, bez obzira na to o kojem djelu govorimo, mogao je lako zaključiti da ima posla s teološkim Hansom Christianom Andersenom. Rebićeva djela odišu biblijskom porukom koju u rebićevskom interpretativnom stilu karakterizira njegov osebujan literarni stil kojim su spomenuta djela pisana. To se posebice odnosi na njegovu knjigu Isusovo uskrsnuće, koja je početkom sedamdesetih godina prošloga stoljeća, u vrijeme kada je prvi put bila objavljena, izazvala žustre, ozbiljne i kompleksne polemike unutar tuzemnih teoloških krugova. Rebić na jednom mjestu u spomenutoj knjizi opisuje poveznicu između Židova i kršćana tumačenjem onoga što je objema religijama zajedničko - koncept života, na sljedeći način:

$\gg$ (o)va teološka predodžba [Lk 24.5, nap. a.] o živome Isusu uzeta je uostalom iz starozavjetne židovske teologije. Jahve je u Starome zavjetu označen kao 'živi Bog' (usp. Br 14,21.28; Pnz 5,26; 32,40; Ez 5,11). U Starom se zavjetu ljudi zaklinju Bogom 'živim' (usp. 1 Sam 19,6). $\ll^{30}$

O Adalbertu Rebiću možemo govoriti kao o piscu koji je posjedovao osjećaj za suptilniji izraz kojim je posljedično u pozitivnom smislu inficirao užu, specijalnu, akademsku, jednako kao i širu čitateljsku publiku, posebice onaj njezin dio koji broji oko 4000 duša koje su imale priliku prisustvovati na jednom među mnogim stručno-turističkim putovanjima, tj. hodočašćima u Svetu zemlju. Ta je putovanja Rebić višekratno i godinama organizirao, ističući time značenje religijski shvaćenoga i teološki protumačenoga koncepta hodočašća, a o čemu i sâm Rebić, među ostalim, piše u članku Hodočašća u Svetu Zemlju u posljednjih 100 godina (1985.).

\section{Metasmisao $\gg$ jednog $\ll$ hodočašćenja}

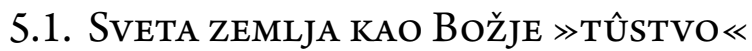

Ono što se može izdvojiti kao posebnost Rebićeva stvaralaštva jesu njegova hodočasnička putovanja po Svetoj zemlji. Ne samo da u tuzemstvu i izvan njega nema čovjeka koji je više puta pohodio Svetu zemlju od Adalberta Rebića. Jednostavno takvoga nema. Primjerice, s filozofskoga gledišta promatrano, ono što ne postoji, može jednom postati. No, ako nečega nema, onda to zaista ne postoji: bitak jest,

${ }^{30}$ A. REBIĆ, Isusovo uskrsnuće, 107. 
nebitak nije - klasično ontološko načelo. Zato s posebnom obzirnošću želimo u nekoliko sljedećih redaka kazati ponešto (ne toliko o Rebićevim hodočasničkim putovanjima po Svetoj zemlji, nego) o samoj knjizi - o Vodiču po Svetoj zemlji. Jer to djelo, svojim pomno izabranim ilustracijama koje na jedan način predstavljaju memoare Rebićeva života u Svetoj zemlji, također slikovno doprinosi razumijevanju Svete zemlje općenito. Zemlje koja u geografskom pogledu predstavlja jednu dijalektiku: plodna Galileja, suha Judeja. Njezina eshatološka poruka: Isusovo uskrsnuće. Njezine ontološke zadatosti obuhvaćene izrazom sveta - to je zemlja Boga objavljenoga, raspetoga, uskrsloga, zemlja Boga živoga kojemu se klanjaju vjernici i hodočasnici triju svjetskih religija: judaizma, islama i kršćanstva.

Sveta je zemlja Božji dom - ne samo za Adalberta Rebića već za svakoga onoga, bez obzira na to bio on/ona vjerujući ili nevjerujući, tko jednom u nju kroči. Tako opisan doživljaj Svete zemlje stječe svatko tko uzme u ruke i pomno pročita Rebićev Vodič po Svetoj zemlji. To nije vodič u klasičnom smislu te riječi, to je priča koja će svakoga uvući $\mathrm{u} \gg$ stvarskost « (Heidegger) te svetosti svete zemlje, $\mathrm{u}$ bît njezine (biblijsko-)teološke poruke: Bog se objavio ljudima, činom objave na mjestu te objave ukazao se tim ljudima - izabranim ljudima, i samim činom objave, prema kršćanskom vjerovanju, inkarnirao se, uzevši ljudsko obličje, da bi čovjeku postao bliži, s njime stupio u kontakt - uspostavio konverzaciju. Tu diskurzivnost Božje objave Rebić lijepo oslikava i dočarava u Vodiču. Svetu je zemlju stoga moguće misliti kao pathos te diskurzivnosti, premda ona za Rebića sâma u prvome redu postaje i ostaje Božji dom - mjesto rođenja i objave »živoga Boga «, ne predmet filozofijskih objektivacija koje idu u smjeru - da posudimo Taylorov izraz koji je on pak preuzeo od Maxa Webera - »raščaravanja « onoga što tu zemlju, Izrael (nap. a.), čini istinski svetom.

Sveta zemlja, ako njezinu poruku propitujemo teološki, egzegetski, služeći se fenomenološko-ontološkim Heideggerovim spoznajnim uvidima prezentiranim u njegovu Bitku i vremenu, gdje je Heidegger pokazao kako izgleda temporalna struktura »bivstvovanja-u-svijetu «, dakle Sveta zemlja predstavlja prostorno-vremensku determinantu očitovanja onoga što filozofi običavaju dohvaćati u sintagmi bitak bića. Bog, filozofskom metodologijom razumijevan kao Heideggerov bitak (Bog koji jednostavno jest), sebe očituje kao onaj koji je »tû/bitak «. Tako da Sveta zemlja, a te uvide imamo zahvaliti Adalbertu Rebiću koji ju je svojim Vodičem približio i onima koji još nisu bili u prilici posjetiti - teološki mišljeno - dom Gospodnji, predstavlja to tû-stvo Boga živoga kao bitka koji je tû; koji tû stanuje; tû obitava. Kao što rijeke imaju svoj izvor u planinama, tako i očitovanje Boga ljudskom rodu ima svoj izvor - u planini, na Sionu, u Svetoj zemlji. 


\subsection{Vodič Po SVETOJ ZEMLJI: SINOpSIS}

Uz mnoge literarne izvore konzultirane radi pisanja ovoga rada, ovdje bih detaljnije govorila o tome što je Sveta zemlja značila Adalbertu Rebiću. Kako bi se saznao odgovor na spomenuto pitanje, valja nam uzeti u ruke njegov briljantni Vodič po Svetoj zemlji (dalje ovdje i u bilješkama: Vodič) i pročitati ga od korica do korica jer čitanjem te knjige opsegom razasutoga sadržaja na nešto više od dvije stotine stranica čitatelj se uistinu uživi u Rebićev opis. Ne samo u opis istaknutih arhitektonskih mjesta u Izraelu, osobito u Jeruzalemu, nego u Rebićev opis te dinamike hodočašćenja koja naizgled poprima forme turističkoga provođenja putnika kroz Svetu zemlju, Izrael, zapravo je, u svojoj biti, jedna velika učena šetnja s Adalbertom Rebićem putovima Božjim. Šetnja u maniri grčkih peripatetika: Adalberta i njegovih hodočasnika.

»(I)z Hrvatske koji posvećuju Svetu zemlju. Ja [Adalbert Rebić, nap. a.] sam u posljednjih četrdeset godina (od 1966 do 2005) bio s hodočasnicima u Izraelu osamdesetak puta. Samnom je svaki puta bilo u prosjeku po pedeset hodočasnika! To znači, samnom je Svetu zemlju posjetilo oko četiri tisuće hodočasnika. Oni su zavoljeli Svetu zemlju više nego li ikoji drugi kraj koji su ranije posjetili. Ima tomu više razloga $\ll$,

piše Rebić u predgovoru VI. izdanju Vodiča. U nastavku izlaganja ne ću se zadržavati na značenju i teološkoj poruci hodočašćenja u Svetu zemlju jer to nije tema ovoga rada, ali nadamo se da će prilike ipak biti jer bi bilo zanimljivo uvidom u Rebićev teološki opus načiniti jedan povijesno-teološki presjek geneze hodočašćenja koja, vjerojatno, imaju svoj korijen u Starom zavjetu. U nastavku ću reći nešto o samome Vodiču.

Već sam prethodno kazala da Vodič obuhvaća literarni i ilustrativni materijal raspodijeljen na dvjestotinjak stranica. Rebić je potkrijepio fotografskim svjedočanstvima istaknuta mjesta Svete zemlje koja su u uskoj povezanosti s poviješću spasenja i Isusovim uskrsnućem. Slijedi sinopsis tema po poglavljima:

- općenito o hodočašćima u Svetu zemlju (str. 11-20.), obuhvaća i ulomak o znamenitim Hrvatima u Svetoj zemlji (npr. sv. Jeronim, autor Vulgate: str. 17-20.)

- zemljopisno-klimatski prikaz Svete zemlje: povijest, involviranost islama, grad Jeruzalem itd.

- Novi Jeruzalem i Ain Karim

- Betanija - Jerihon - Mrtvo more - Kumran - Masada

- Emaus

- Put od Jeruzalema do Nablusa (Šekema) 
- Šekem - Samarija

- Galileja

- Nazaret - Haifa - Karmel

Dakle devet poglavlja ili tematskih blokova zajedno s predgovorom čine deset metodološki zasebnih segmenata Vodiča, slijedom biblijski shvaćenoga simbolizma brojeva, konkretno, broja deset: Deset zapovijedi koje je JAHVE dao Mojsiju na brdu Sinaj (Izl 20, 2-17; Pnz 5, 6-21). To nam, među ostalim, govori kako je Rebić pazio i na biblijski, starozavjetni simbolizam brojeva pri strukturiranju sadržaja Vodiča.

Što Vodič čini posebnim Rebićevim djelom, vrijednim da mu se da posebna pozornost ovdje? To je, smatra se, neumitno jezik autora sâma. Jednostavan jezik, da ne kažemo cesarićevski poetski jezik. Zatim je to Rebićev stil pisanja: pitoreskan, povijesno precizan, teološki intrigantan poradi simbolizma, literarno pitak jer obiluje deskriptivnim elementima. Lakoća objašnjavanja: kronologijski slijed razbijen deskripcijama okružja, ljudi, navikâ. Metodičnost izlaganja koja obuhvaća troje: geografsku metodičnost, znanstvenu akribiju i teološko nadahnuće.

Osim dobroga poznavanja biblijske arheologije, koja je bila Rebićeva uža specijalnost, u Vodiču se pokazao kao čovjek koji posjeduje istančan osjećaj za »spacijalnu orijentaciju $\ll^{31}$, orijentaciju u prostoru Svete zemlje, koji i na papiru Rebić umije predočiti kao da šeće Svetom zemljom, bez obzira na to je li riječ o otvorenom prostoru poput Maslinske gore gdje je »Isus volio boraviti $\ll,{ }^{32}$ kaže Rebić; $\gg$ Getsemanskom vrtu « koji uopće nije »vrt europskog stila, (...) (t)o je maslinik «,33 naglašava Adalbert Rebić. »Silazimo u crkvu Marijina Uznesenja koja bî podignuta na mjestu gdje bijaše Marijin grob ${ }_{3,}{ }^{34} \mathrm{ili} \gg$ tek što smo ostavili grad Jeruzalem, evo nas u biblijskom mjestu Betaniji $\ll,{ }^{35}$ ili smo se zatekli na cesti »što vodi iz Jeruzalema prema Samariji (prema Nablusu) $\ll^{36}$ kako bismo posjetili Emaus koji je »samo 18 $\mathrm{km}$ udaljen od Jeruzalema $\ll,{ }^{37}$ ili odlazimo $\mathrm{u} \gg$ Šekem gdje je Jošua sazvao skupštinu sinova izraelskih i održao im glasoviti govor (Jš 24) o vjernosti Bogu Jahvi $\ll,{ }^{38}$ ili

\footnotetext{
${ }^{31}$ Izvorno Heideggerovim pojamom kojemu je Charles Taylor u Izvorima sebstva dao etičko značenje ovdje se koristimo kolokvijalno i u geografskom smislu.

${ }^{32}$ Usp. A. REBIĆ, Vodič po Svetoj zemlji, Zagreb, 2010., 58.

${ }^{33}$ Isto, 63.

${ }^{34}$ Isto, 67.

${ }^{35}$ Isto, $135 \mathrm{ss}$.

${ }^{36}$ Isto, 151 .

${ }^{37}$ Isto.

${ }^{38}$ Isto, 161.
} 
smo otišli do Jafe ${ }^{39}$, pa nam se $\gg$ obično jako žuri. Treba stići na zrakoplov u Lod (...) Nedaleko od Lide, odnosno Loda, je mjesto Modiin, rodno mjesto slavnih Makabejaca. Tu su oni pokopani. U hazmonejsko doba bio im je podignut veličanstveni spomenik od kojega su danas vidljive još samo ruševine. Od 1910. godine redovito dolaze za blagdan Hanuku mladi Židovi u Modiin na logorovanje. U čast Makabejcima pale baklje i rasvjetljuju noć za blagdana Hanuke, blagdana svjetlosti $\ll{ }^{40}$

Čitajući ili slušajući taj, ovdje tek u obrisu i napreskok iznesen, kratki putopis Rebićevom Svetom zemljom, čitatelj ili slušatelj zaista može steći dojam da primjerice stojeći ispred Omarove džamije

>u duhu može zamisliti crkvu Uzašašća. I njezin materijal je u džamiju ugrađen. (...) Na blagdan Uzašašća muslimani dozvoljavaju franjevcima da ovdje slave euharistiju. $\ll{ }^{41}$

»Silazimo, dakako uvijek pješice po Svetoj zemlji poseban je čar - prema Getsemanskom vrtu. S lijeve strane ostavljamo suvremeno židovsko groblje. Židovi se ovdje pokapaju u nadi da će biti sasvim blizu Mesiji kad ih on uskrisi i s njima slavodobitno uđe u oslobođeni Jeruzalem. No, muslimani su im simbolički Zlatna vrata zazidali $\ll^{42}$

Kada bismo željeli sumirati sveukupni sadržaj predočen u Rebićevu Vodiču, ne bismo mogli previdjeti ključno pitanje koje probija između redova Rebićeve interpretacije ključnih biblijskih mjesta, starozavjetnih i novozavjetnih običaja, semitskih ljudi i svetih stvari koje su odigrale ulogu u povijesti spasenja, u Isusovoj osobnoj povijesti, a to pitanje glasi: Što je židovstvo za Adalberta Rebića? To nije samo pitanje već pitanje koje je ujedno i dogovor na pitanje samo. Religijski mišljeno, Rebić je židovstvo smatrao korijenskom religijom kršćanstva:

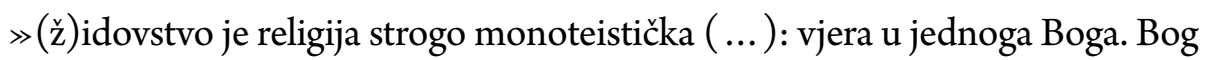
je stvorio svijet i nije ga ostavio, nego se za nj i dalje brine. Od ljudi Bog očekuje obraćenje i ispovijedanje vjere u njega kao jednoga i jedinoga Boga. ${ }^{43}$

\section{Zaključak}

O Rebićevu doprinosu teološkoj znanosti i filologiji. Osvrnuvši se na prethodno napisane retke koji većim dijelom daju, ovdje tek u ocrtu izneseno, svjedočan-

\footnotetext{
${ }^{39}$ Isto, 219-220.

${ }^{40}$ Isto, 221., 223.

${ }^{41}$ Isto, 59., 61.

${ }^{42}$ Isto.

${ }^{43}$ Isto.
} 
stvo o dvoje: (1) o prešutnoj činjenici da je odlaskom Adalberta Rebića tuzemni akademski i kulturni krug izgubio jednu znanstvenu, spisateljsku i ljudsku veličinu. Izgubio je čovjeka čijem je znanju i poznavanju hebrejskoga jezika, kao i biblijske teologije u nas malo tko filološki i teološki pandan. (2) prateći publikacije o temama kojima se bavio Adalbert Rebić (da podsjetimo, biblijska teologija, egzegeza Staroga zavjeta, hebrejski jezik), a neke među njima smo i ovdje načeli, malo je reći da je Adalbertu Rebiću lako naći nasljednika unutar okvira tuzemne akademske zajednice, što za daljnje proučavanje i studiranje znanosti teologije u nas može predstavljati ozbiljan epistemološki i metodološki problem širih razmjera. Rebić je govorio da poznavanje Svetoga pisma i Božje poruke ne ide bez razumijevanja jezika na kojem je Bog, prema biblijskom vjerovanju, stupio u kontakt s čovjekom bez poznavanja hebrejskoga jezika; jezika koji je Rebić nazvao »božanskim«. Jer poznavati jezik ne znači poznavati tek nekoliko stranih riječi, kako objašnjava Rousseau u Émileu. Poznavati jezik znači (u)poznati njegov duh i s njime srasti - poznavati duh jezika. Zato nam je Heidegger bio neizostavno važan za ovo naše promišljanje koje u metodološkom pogledu formom više predstavlja autoričina osobna promišljanja izabranih tema iz Rebićeva biblijsko-teološkoga opusa s naglaskom na koncept židovstva jer je njime obuhvaćeno heideggerijansko razumijevanje rebićevski interpretirane bîti hebrejskoga jezika (1) koji ima svoju višetisućljetnu povijest koja je zajednička Židovima i kršćanima, (2) koji je u toj povijesti odigrao ključnu ulogu u razumijevanju i očuvanju judeokršćanske vjere, (3) koji je relevantan za razumijevanje mentaliteta semitske kulture općenito, (4) koji predstavlja ishodišnu točku u razumijevanju teologije i judeokršćanske religije, (5) koji, uz filologiju i biblijske znanosti (teologije) može biti i predmet izučavanja i propitivanja filozofije u segmentu koji se tiče ljudskoga razumijevanja općenito jer geneza toga jezika upućuje na ono što je Platon kroz Sokratova usta u Menonu kazao za vrlinu: »vrlina se dodjeljuje odozgo «, dakle njezin izvor jest milost. Analogno tome, a slijedeći genealogiju ljudskoga jezika općenito mogli bismo kazati da je jezik dar odozgo: metafenomen koji je bio i vazda će biti objektom istraživanja različitih znanosti i filozofijskih promišljanja. Ako je prema Heideggeru »jezik kuća bitka «, a teologija nas uči da je taj bitak Bog, onda je hebrejski jezik, kako je to razložno pokazao Rebić u svojim istraživanjima hebrejskoga jezika i biblijske teologije, neumitno kuća Boga. Tako da možemo govoriti o dvojakom doprinosu Adalberta Rebića semitskoj filologiji i teološkoj znanosti (filozofijskoj hermeneutici i ontologiji, također), i na našim prostorima i izvan njihovih matičnih granica. Adalbert Rebić uveo je hebrejski jezik u tuzemnu akademsku zajednicu i time uvećao djelokrug toga jezika i izvan područja teologije i teoloških disciplina. Dakle Rebićev znanstveni doprinos prije svega valja promatrati u kontekstu učiteljskoga poziva kojemu je bio imanentan onaj svećenički jer i za jezik se može reći da predstavlja put k određenom pozivu. 
O epistemičkoj izvrsnosti i metodološkoj ispravnosti Rebićeva opusa i njegove tematske klasifikacije. U ekonomskoj praksi postoji sljedeća klasifikacija i kvalifikacija zaposlenika: dobri, uspješni, izvanredni. Pokušamo li tu ekonomsku klasifikaciju vrjednovanja načina ljudskoga djelovanja (rada) u poslovnom svijetu preslikati na Rebićev teološki rad i doprinos tuzemnoj akademskoj zajednici, biblijskoj znanosti prije svega, Rebić bi govorom suvremenoga ekonomista praktičara kojemu je uža specijalnost menadžment kvalitete i ljudskih resursa spadao u najvišu vrijednosnu klasifikaciju, među izvanredne. Ta klasifikacija radne izvrsnosti, uz navedeni stupanj uključuje još i dobre i uspješne. Dobre treba natjerati da slijede put uspješnih, a uspješne motivirati da postanu izvanredni. No treba imati hrabrosti za priznavanje zasluga ljudima koji su to priznanje uistinu zaslužili, a među takve nedvojbeno spada Adalbert Rebić, prije svega zahvaljujući osobnoj karakternoj postojanosti i daru za prenošenje i tumačenje Božje poruke služeći se znanstvenom metodologijom.

O pitanju sistematičnosti Rebićeva znanstvenoga opusa s osvrtom na teologiju uskrsnuća u Isusovu uskrsnuću. Rebić je, kako smo to prikazali u t. 4.1., promišljao i pisao o onim temama koje su nužne i nezaobilazne za razumijevanje bîti kršćanske vjere. U prvome redu to je Isusovo uskrsnuće. Dakle Bog, a onda njegov dom - Sveta zemlja (t. 5.2.). Takvim sustavnim pristupom razumijevanju Božje egzistencije Rebić se afirmirao kao sustavni teolog, više od pukoga pisca o kakvom je bilo riječi u t. 1 . U odnosu na samo pitanje fundiranja Rebićeve misli u smislu integralnoga egzegetskoga sustava, u čijem se središtu nalazi duboka analiza Božje spasenjsko-otkupiteljske poruke, a to se dâ ustvrditi temeljem pomne analize njegovih misli kojima je obuhvaćena problematika Božje objave (eksplicirane u djelima Stvaranje svijeta i čovjeka i Središnje teme Staroga zavjeta) shvaćene kao jezik, uskrsnuće kao metajezik još je uvijek neprepoznatljivo i neshvatljivo Židovima i židovstvu i nakon pune dvije tisuće godina. Ono što se zaključno nameće, proučavajući Rebićev biblijsko-teološko-literarni opus, jest tvrdnja da je uskrsnuće domet sveukupne spasenjske povijesti opisane u Starom i Novom zavjetu. Uskrsnuće je Božji jezik kao odgovor na ispunjenje, ali nipošto dovršenje spasenjske misije jer spasenje podrazumijeva mnogo više od temporalno-spacijalne određenosti. Ono podrazumijeva dinamički kontinuum koji je Rebić tako lijepo opisao u prvim redcima predgovora u Isusovo uskrsnuće - podrazumijeva vjeru:

$\gg \mathrm{O}$ malo kojem otajstvu naše vjere se toliko raspravlja, i među teolozima i među ostalim vjernicima, koliko o uskrsnom otajstvu smrti i uskrsnuća Kristova. I s potpunim pravom! Otajstvo Kristova uskrsnuća srce je i temelj naše vjere: 'Ako Krist nije uskrsnuo onda je neosnovano naše propovijedanje, neosnovana je i vaša vjera $(1$ Kor 15,14$),{ }^{44}$

${ }^{44}$ A. REBIĆ, Isusovo uskrsnuće, 13. 
Rebićevo djelo Isusovo uskrsnuće, osim što predstavlja nezaobilazni izvor za razumijevanje izabranih teoloških disciplina i vjere kao takve, ono, ako ga se iščitava filozofijskim, hermeneutskim jezikom, predstavlja metaepistemički izvor relevantan za ono što filozofija dohvaća u pojmu bitka: ako bitak jest, a teološki pojmljeno uskrsnuće interpretirano $u$ duhu Rebićeve teološke misli označuje život ${ }^{45}$, a uskrsnuće je život (Lk 24, 5), dakle život jednostavno jest, a život po uskrsnuću onda predstavlja nastavak toga jest - budućnost, a što je budućnost drugo nego li vremenska ekstaza (Heidegger). To znači da je čovjekov život u kontekstu uskrsnuća moguće shvatiti kao kretanje kroz vremenske ekstaze: » bilost, sadašnjost i budućnost «. Potonje za Heideggera označuje egzistenciju. Slijedi da je uskrsnuće, kako ga opisuje Rebić u Isusovu uskrsnuću metaegzistencijal. Rebić objašnjava da je

>teološka predodžba o živome Isusu uzeta uostalom iz starozavjetne židovske teologije (...). U Starom se zavjetu ljudi zaklinju Bogom 'živim' (usp. 1 Sam 19,6$) \ll{ }^{46}$.

Tu je evidentna jedna dijalektika života čovjeka, ali i njegova Stvoritelja - Boga koji je morao umrijeti da bi se ponovno rodio. ${ }^{47}$ Sâm $\gg$ događaj uskrsnuća « prema Rebiću upućuje na to da je uskrsnuće akt. Riječ događaj, premda je u tuzemnom jeziku imenica, $k$ tome gramatički pojmljeno označuje subjekt ili objekt. Da bi se neki događaj uopće dogodio, potrebni su pokretač te radnje i radnja. U kontekstu uskrsnuća Kristova Bog je ujedno i pokretač te radnje i radnja za sebe - actus purus (sv. Toma Akvinski).

O Rebićevu teološko-literarnom i filološkom opusu kao znanstvenom, akademskom, kulturnom i dijaloškom naslijeđu. Kao nekadašnjoj studentici i diplomantici studija teologije pri KBF-u u Zagrebu, koja je imala čast uživo slušati predavanja Adalberta Rebića - te jedne antropološke veličine, erudita, poliglota, izuzetno nadarena predavača, pravoga eksperta u poznavanju i tumačenju semitskih kultura i jezikâ, autentična posredovatelja Božje riječi u akademskim krugovima i izvan njih, izuzetna mi je čast pisati o dr. Adalbertu Rebiću čija su predavanja, ljudska susretljivost, posebice evidentna u razdoblju koje obuhvaća prvu polovinu devedesetih godina 20. st., naklonost prema čovjeku, kao i izuzetan propovjedničko-predavački dar ostavili značajan biljeg u mojem osobnom i profesionalnom životu. Čitajući i propitujući sadržaj literarnoga opusa Adalberta Rebića nameće se zaključak da se ima posla ne samo s čovjekom koji je bio lak na peru, čemu svjedoči nebrojeno mnogo njegovih uradaka u području biblijske teologije i egzegeze Sta-

\footnotetext{
${ }^{45}$ Isto, 106.

${ }^{46}$ Isto, 107.

${ }^{47}$ Isto, 83.
} 
roga zavjeta, s posebnim osvrtom na Rebićev interes za razumijevanjem događaja Isusova uskrsnuća, već se tu operira sa spoznajama koje su relevantne i za studij teologije i za razumijevanje kršćanske vjere na individualnoj razini. Adalbert Rebić je s toliko ljubavi pisao o Bogu da njegova literarna djela, među ostalim, daju svjedočanstvo i o jednom osobnom odnosu između njega i Boga. $S$ tolikim oduševljenjem sastavio je Vodič po Svetoj zemlji da bi ta knjižica, smatram, obratila svakoga čovjeka koji o Bogu razmišlja na način drukčiji od onoga koji nudi teologija ili pak kršćanskom mišlju nadahnuta filozofija.

Adalbert Rebić svojom humanošću i intelektualnom izvrsnošću bjelodanima u nastojanju nadilaženja konflikata koji su tijekom povijesti emanirali s jedne i druge strane (Odnos izmedu Židova i kršćana kroz povijest, 2007.) zadužio je hrvatsku akademsku zajednicu, kao i njezine studente (koje je učio) i mnoge druge institucije i subjekte, pogotovo one koje su bilo izravno ili neizravno sudjelovali u promicanju židovstva, židovskoga identiteta i hebrejskoga jezika jer, uvodeći mnoge u tajne hebrejskoga jezika, Adalbertu Rebiću pošlo je za rukom da perom očuva novozavjetnu poruku »da svi budu jedno « (Iv 17, 21-23) - judeo(kršćanski) identitet i židovsku baštinu, posebice grada Zagreba i njegova akademskoga i kulturnoga kruga kojemu je supsumiran i zagrebački židovski kulturni krug unutar kojega je ime Adalberta Rebića ostavilo neizbrisiv trag. U Rebićevu žaru kojim je ljubio hebrejski jezik i biblijsku, židovsku teologiju može se prepoznati način na koji je moguće bez prisutnosti povijesno začetih i doktrinarno-ideološki nametnutih konflikta i zamjerki a conto trvenja između Židova i kršćana sačuvati oba identiteta: židovski jednako kao i kršćanski jer i jedan i drugi izviru iz jednoga te istoga korijena - hebrejskoga jezika koji još uvijek, unatoč sveprisutnom modernitetu obilježenom sekularnim duhom, ima značenje i ulogu manje u obrednom, no više u društveno-kulturnom životu - posebice Židova u Hrvatskoj. 


\section{DISCOVERING THE SIGNIFICANCE AND MEANING OF THE CHOSEN THEMES AND MOTIFS OF THE BIBLICAL-THEOLOGICAL WORK OF ADALBERT REBIĆ}

\section{Dafne VIDANEC*}

Summary: In the philosophical expression of the prominent names of the philosophical hermeneutics of the 20th century (Heidegger and Gadamer) the paper discusses the meaning and significance of Judaism and the closely related Hebrew language in view of the insights of the biblical-theological work of Adalbert Rebic. Adalbert Rebić was a famous Croatian theologian, Bible scholar, polyglot, Hebraist, university professor, and Roman Catholic priest. In academic, as well as in wider cultural circles in the country and abroad, Adalbert Rebic is remembered as an expert on Hebrew language and Judaism. Everyday people and the media remember the name of Adalbert Rebic thanks to his selfless engagement in the field of public services in the early 1990s in the Government Office for Displaced Persons and Refugees. Dozens of generations of students at the Catholic Faculty of Theology at the University of Zagreb remember the moment when Adalbert Rebic $\gg$ introduced them to the secrets of the Hebrew language « - the language in which God spoke to people; the language that played a key role in understanding the history of salvation and the New Testament message of Jesus' resurrection. And, perhaps, his name is best remembered by pilgrims whom Adalbert Rebic had taken countless times to the Holy Land. The Hebrew language, Judaism, Jesus' resurrection, and the Holy Land are just some of the motifs and themes that will be discussed in the content of this work, which is conceptually divided into three parts (though it methodologically includes six parts): in the first part of the work, in a way that is inherent only to poets - the author uses metaphors to focus on understanding Adalbert Rebic as a writer, where the key role, as the author observes, belongs to his personal identity, i.e. the character consistency manifested in all his expert works. The second and largest part of the paper covers the topics of language, the classification of Rebic's works with emphasis on the issue of the Hebrew language and Judaism. The third part brings the author's personal reflection on the $\gg$ Rebicly 4 understood ontology of a pilgrimage, that is, the synopsis of main themes and motifs in the $\gg$ Guide through Holy Land «, since this work, according to the author's personal opinion, besides the $\gg$ Resurrection of Jesus $\ll$, is crucial for understanding Adalbert Rebic, and his life and work.

Keywords: Adalbert Rebić, identity, Judaism, Hebrew language, Holy Land.

* Dafne Vidanec, Ph. D. Phil; RA IDP, University of Applied Sciences Zaprešić, Vladimir Novak St 23, 10290 Zaprešić, dvidanec@bak.hr 